\title{
The Bilingual School Program Management
}

\author{
Eko Prayitno*, Sutarto Hadi, Muhammad Saleh \\ Master of Educational Management Program, University of Lambung Mangkurat, Banjarmasin-South Kalimantan
}

\begin{tabular}{|c|c|}
\hline ARTICLE INFO & A B STRACT \\
\hline \multirow[t]{2}{*}{$\begin{array}{l}\text { Article history } \\
\text { Received: June } \\
\text { Revised: August } \\
\text { Accepted: September } \\
\text { Keywords: management, } \\
\text { program, school, bilingual, } \\
\text { bilingualism }\end{array}$} & $\begin{array}{l}\text { At the moment, the number of bilingual middle schools is highly limited, however, } \\
\text { there is one public and one private middle school in Banjarmasin. The purpose of } \\
\text { this study therefore, is to understand the planning, implementation and evaluation } \\
\text { of bilingual school programs and their subsequent assessment and constraint, using } \\
\text { qualitative descriptive method, with a case study approach. Furthermore, the } \\
\text { analysis derived the following conclusions: Schools that run a bilingual education } \\
\text { plan, do so according to their personal goals and objectives, private institutions } \\
\text { possess the freedom to implement the program, evaluation of multi-lingual } \\
\text { educational organizations occur with the same frequency, objectives and goals as } \\
\text { conducted in other schools. The challenge, or limitation, observed in these } \\
\text { institutions is that not all students are comfortable in a bilingual learning } \\
\text { environment. This report further recommends that relevant educational agencies } \\
\text { should provide opportunities for teachers to participate in international linguistic } \\
\text { forums and principals should also develop a language certification program for } \\
\text { staff. There is a need for teachers to consistently develop their English-language } \\
\text { skills and that researchers should continue to focus their analysis on one aspect of } \\
\text { bilingual school management. }\end{array}$ \\
\hline & $\begin{array}{l}\text { (C) () () } 2019 \text { The Authors. Journal of K6, Education, and } \\
\text { Management (j-K6EM). ISSN: 2580-2135. Published by } \\
\text { Graduated Program of Educational Management, } \\
\text { Universitas Lambung Mangkurat, Banjarmasin 70123, Indonesia. This is an } \\
\text { open access article under the CC-BY-SA license. }\end{array}$ \\
\hline
\end{tabular}

*Correspondence: Eko Prayitno; E-mail: ekoparingin@email.com 


\section{Introduction}

The process of fostering strong international relationships requires young Indonesians to master foreign languages, English especially. However, this is important because it is the most commonly used international language and it is one of the six official international dialects, listed by the United Nations (UN), others include, Spanish, French, Arabic, Chinese and Russian. Furthermore, this makes English a compulsory subject for secondary education, hence onethat is tested in National Examination subjects.

The Indonesian Government's policies, requires that English in secondary schools and local communities are more aware of its importance in many societal functions. Furthermore, evidence has shown that bilingual course institutions are expanding into various regions and cities across Indonesia and students and members of the local, general community, academics and other professionals enroll for this program.

As the name suggests, bilingual schools utilizes two languages in constructing classroom and surrounding conversations and teachers use both Indonesian and English in their delivery. These special schools provide the skills needed in today's society by delivering fluent learning outcomes in middle school, which requires that all subject teachers have satisfactory English-language competence.

Education management also includes all that is related to the administration of the dialect learning process, hence, the objective is to achieve the short, medium and long-term goals of improving edifying outcomes (Mulyasa E., 2009).

Supervising a school makes provision for an effective workplace experience for administering other educational entities. Furthermore, the administration of educational institutions possess similar pursuits, which can be considered from three points of view, which includes as, a science, an art and an activity process (Suprihatin, 2004).

Similarly Chin \& Wiggleworth (2007) separated bilingualism skills into 2 (two) categories (types), including, balanced bilingual, involving the satisfactory eloquence of someone in a different context, here, the achievement has not been obtained because Indonesia still takes English as a foreign language and not an official language for public instruction. Furthermore, the second is dominant bilingual, where someone is more likely to use one language only in bilingualism. Hopefully, the second type can be applied in the education system in Indonesia today.
Schools should carefully and measurably prepare a program and some terms often used when creating a bilingual school, include staffing, teacher recruitment, teacher certification or staff development and curriculum advancement (Pranowo, 2005)

In bilingual lessons, it is normal to have teacher collaboration in a class because the use of multilingual schoolroom learning models and the partnership in a study, suggesting that this collaboration is very beneficial to both instructors (Lee, 2008). Furthermore, English teachers should possess an awareness of potential linguistic problems that could arise from other tutors in certain subjects and other positive factors on why the activity should be adapted should also be considered.

The purpose of this study is to get an overview of Planning, Implementing, evaluating of the bilingual program. Beside, following up, and obstacles of the bilingual program at The State Middle School of Paringin 4 and The Middle School Al Mazaya of Banjarmasin.

\section{Methodology}

In accordance with the research theme, the approach used was descriptive qualitative analysis, which is relevant in the evaluation of problems that requires the conducton of a critical study, to enhance understanding and clarification, through an intensive relationship with the data source.

However, from the type, this research is also attributed to conduct the strategy of a case study. Furthermore, the data obtained were based on planning, implementation and evaluation of schools with bilingual programs and also, a follow-up with constraints of programs were further sought.

The research data to be sought include staff recruitment, teacher sertification, curriculum development and staff development. Especially for curriculum development, the data tobe developed include lesson plan, school facility, English community, and classroom activities.

The sources of information obtained in the investigation included the Principal, Vice of Principal for Curriculum Fields and the Teachers, with techniques, including interview, documentation and observation. The analysis method involved cross-site data, with the purpose of comparing information and also integrating findings obtained from each site studied.

Furthermore, the data acquired from The State Middle Schools of Paringin 4 and Al Mazaya of 
Banjarmasin, were tested in stages for their validity, using Triangulation.

To guarantee the legitimacy of the information obtained, the following techniques were applied: Firstly, Credibility Test, here, the criterion aims to prove that the data collected in the field, really contains truth values, by applying the extension of observation, increasing perseverance and triangulation. Secondly, Dependability Test, which involves an audit of the entire research process. Furthermore, after field observations, analysis was conducted on the data, which drew a conclusion that the research was actually carried out. Thirdly, Conformability Test, carried out simultaneously with dependability, involves the examination of the results of research. This was further expected to increase the quality of the investigation conducted.

\section{Findings and Discussion}

The State Middle School of Paringin 4 is the only public bilingual school in South Kalimantan. The school has a National Examination achievement that is prominent in English subjects. Whereas The Middle School Al Mazaya of Banjarmasin is a private junior high school that also has good achievements in terms of English especially at the junior high school level in Banjarmasin. The students often win various English language skills competitions.

This study identifies several aspects of management, which includes planning, implementation and evaluation and further reviewed the follow-up and obstacles in the bilingual school program.

From the planning aspect, the Short Term strategy at The State Middle School of Paringin 4, include, the research site, recruitment of educators and education staff, learning materials and the school curricula. However, the Medium Term Plans include certification of English language skills and professional development for teachers and other education staff. Furthermore, the Long-term Plan was curriculum development.

Conversely, at the second research site, The Middle School Al Mazaya of Banjarmasin, same reports were observed for short, medium and long term plans as with the first research site.

At The State Middle School of Paringin 4, the following were observed: Recruitment, involved that teachers and administrative staff in the school were from the selection of Civil Servants and Contractors, which is in line with the authority of the Balangan
Regency Government and the Education and Culture Office.

Conversely, regarding learning materials, the Education Unit Level Curriculum (KTSP), using the 2013 curriculum (KI3) and 2006 was developed. The old curriculum (2006), was however still used in class IX (nine), while KI3 was applied in class VIII (eight) and VII (seven). Furthermore, extra learning in English subjects, commonly called Local Content was given 2 (two) hours per week, using specific guidelines available at The State Middle School of Paringin 4, not involving material source from National Publishers in general. The information provided is mostly from A Basic Course English Nine Hundred, which aims to improve the ability of students, especially in speaking skills.

Furthermore, Learning Implementation Plan, involves each teacher to gradually make an education Implementation Plan (RPP), to be approved by the Principal. However, the first research site has a strategy format, not much different from other schools, just some differences in presentation and that it is obtainable in 2 (two) languages, Indonesian and English.

English proficiency certification illustrated that Schools in this study did not have a specific policy regarding teacher certification in their English abilities.

Professional Development at Paringin 4 Public High School was regular and continuous. However, this was not always sustained in schools because the activity was also facilitated by relevant agencies, e.g. the Education and Culture Office of Balangan District.

Curriculum Development involved that schools possess communities and facilities that support good bilingual learning, with the focus of utilizing both languages in a balanced manner and promoting collaboration between teachers in bilingual classes.

Conversely, at the Middle School Al Mazaya of Banjarmasin, the following were observed: Recruitment of Educators and Education Personnel criteria used do not exist in other schools as they presented some special requirements for prospective new teachers. Furthermore, the forthcoming tutors must have mastered the teaching skills in their fields, be capable of meticulously reading the holly Qur'an and also take advantage of Information Technology.

Curriculum and Learning Materials used were contained in the document I (one) of the KTSP of Al Mazaya Middle School Banjarmasin, structured to provide guidance on how to implement bilingual schools, thus improving their value. Furthermore, the 
prospectus includes details on how to recruit employees that must master Information Technology, possess multi-media expertise in teaching and have a sound Holy Qur'an memorization skill.

English Language Certification were not required at this school because the skills were required by physical proof, through interviews held in the school, where the proper test for prospective staff was conducted.

Professional Development was absolutely given to teachers, in order to improve their scientific capacity in executing their duties, which was routinely held at the premise.

Curriculum Development approach taken by this institute include encouraging facilities and a bilingual community and school culture, classroom learning, with emphasis on using dialect in the classroom, teacher collaboration and students' understanding of the concept.

The follow-up aspects of the program, both research sites have a high school that is also based on multilingualism in their learning.

The program constraint observed in Paringin SMP 4 was that some students who have not been able to follow the classes properly, which was also discerned in Al Mazaya Middle School, hence, they must be given special treatment and lessons.

In a curriculum that is nuanced with religion, it is known that many private schools, including $\mathrm{Al}$ Mazaya, have a wide space in developing characters that are very positive and the Principal was very instrumental. Furthermore, this research is consistent with that carried out by Suriansyah \& Aslamiyah (2015), at SDIT Ukhuwah Islamiyah Banjarmasin, which stated that the Principal has a religius philosophy in developing schools, hence they can be developed in a modern way, without leaving the aspect of religion.

In the aspects of implementation in both middle schools, there were processes such as the recruitment of educators and administration staff, learning materials, school curriculum, knowledge of plan implementation, certification of English language skills, professional and curriculum development. Furthermore, syllabus improvement involved community and facilities in bilingual learning, classroom education, multilingual school culture, with emphasis on language use, teacher collaboration and learning methods, the use of bilingualism in the schoolroom and assessment of students understanding in dialect education as a custom. Furthermore, these findings are in line with the research carried out by Suriansyah, (20I4), where it was stated that schools must advance their culture to obtain good performance from its residents. The religious culture is also important in advancing the quality of education in bilingual schools which was supported by the research carried out by Karsa (2018), which stated that emotional intelligence from teachers also strongly supports the progress of the institution.

Schools develop curriculum, especially by increasing the number of English lesson hours and also by learning, based on the use of Information and Computer Technology (ICT), which makes teachers increasingly motivated to educate (Permadi 2019). Furthermore, this practice is good for providing more learning experiences in terms of language however these schools offer good facilities for its implementation as Suhaimi \& Rinawati (2018) in a research stated that schools have a great authority in developing education.

Program evaluation is carried out continuously by the institutions. The State Middle School of Paringin 4 conducts program evaluations twice a year, while The Middle School Al Mazaya of Banjarmasin practices this, once a week. However, this is a good step to control the bilingual program hence its development can always be monitored. Furthermore, principals also take strategic steps to advance schools through evaluation, in line with the discovery by Suhaimi \& Khalik (2018), which state that the breakthroughs impacted by the Principal, really determines the progress of the institution. The results further supports the pre-existing research from Suhaimi \& Efendi (2018), which states the important role of a Principal, in relation to the performance of teachers in the learning environment, relating to the methods they apply, while running all the school programs.

The alumni of The State Middle of Paringin 4 were given the freedom to further their education at any high school of interest, however, the Regional Government of Balangan District, provided a place (establishment of a State High School), where Bilingualism was implored in learning, further known as The State High School of Paringin 2, District of Balangan.

The second research site, by its Foundation, was given a place to channel their interests and talents (The High School Al Mazaya of Banjarmasin) and also a bilingualism learning program. Furthermore, the alumni who continued to other schools were also given the widest opportunity as some of them furthered their education in high schools within the vicinity. Providing 
students with opportunities is the right direction to venture into, for those who manage an educational institution because it is a moral responsibility step imprinted in the generation, planned by a particular educational institution. Furthermore, this program is supported by the conducive environment provided by the school, which include, high school with a common base (bilingualism). In a research conducted by Salasiah (2018), it was proven that an encouraging environment also improves a students' character.

The running program cannot be separated from challenges and obstacles hence the State Middle School of Paringin 4 faces several disputes, which include the presence of students who are shy to say English sentences. Conversely, at The Middle School Al Mazaya in Banjarmasin, a small number of students were not fluent in the language, therefore, the school provided treatments in the form of programs, outside the environment. Furthermore, they sent these students to Kampung Inggris (which means English Village), in East Java Province which was a very positive step to improve students' abilities, especially in Speaking Skill. However, the role of schools and school-based management is very important to address the challenges of the program and the two bilingual schools above have good administration hence they can follow up on existing constraints, which is in line with the discovery of Alamsyah (2019), that these Management systems improve school progress.

The private schools are more flexible in fund raising, including finance for developing students' abilities in English, hence, the Middle School Al Mazaya, Banjarmasin, possessed an awareness of this capabilities at an inexpensive costs however, this has become a shared awareness. This Further corresponds with how parents participate in supporting children's education and how institutions maximize School-Based Management, in the educational unit environment and how the relationship with parents is very important as Artini \& Nitiasih (20I4) revealed that parental participation in student education is very important for education can be successful as moral and materials, supports and plays an important role in the implementation of quality education in schools, especially bilingual institutions. Furthermore, it cannot be released by the role of the Principal because they manage and control the school, as research conducted by Rachmadinoor (2018), reported that Principals as managers, educators and motivators, greatly influence the quality of educational institutions.
Non government schools are more flexible in raising funds including funds for developing or enriching students' abilities in English. The Middle School Al Mazaya of Banjarmasin with an awareness of programming enrichment and development of students insights with inexpensive costs. However, this has become a shared awareness. This corresponds to how parents participate in supporting children's education and how schools maximize School-Based Management in the educational unit environment. How this relationship with parents is very important. Artini \& Nitiasih (20I4) revealed that parental participation in student education is very important so that education can be successful. Moral and material support plays an important role in implementing quality education in schools, especially bilingual schools. It cannot be released is the role of the Principal as the principal manager and controller of the school. As research conducted by Rachmadinoor (2018) found that Principals as managers, educators, motivators greatly influence the quality of educational institutions.

The study limitation of theresearch is that the research focuses on the management of bilingual schools according to the school documents. Besides that also finds to whatever school policies relating to management of bilingual programs.

\section{Conclusion and Recommendation}

The conclusions of the research are:

Firstly, in the planning processes, at the State Middle School of Paringin 4 and Al Mazaya of Banjarmasin, which included Staffing, Teacher Recruitment, Certification, Development and Curriculum Development, the bilingual schools took steps that were aligned with the Vision, Mission and Objectives. Furthermore, the institutions ran a plan in accordance with the Leading function, hence also in agreement with the objectives of the educational institution.

Secondly, at the step of program implementation of bilingual schools, both schools had different implementations in the field, where they were adjusted to their individual cultures and structural rules. Furthermore, it is known that The State Middle School of Paringin 4 (as a government institution), has limitations with this implementation because of the regulations that must be followed, while the other institution researched, which was managed by the Foundation, possessed the freedom to determine education policy in the unit environment. However, 
schools develop in science and technology as well as on their religious character which is typical for religiousbased schools.

Thirdly, evaluation phase in a bilingual school indicated that both schools had the same goal, which include, control over all the plans made and also to maintain the quality of learning. Furthermore, the difference was actually in terms of frequency in conducting evaluations, where the private school evaluated more often than The State government School, within one year.

Fourtly, the follow-up on the institutions were conducted to establish a High School, based on bilingual. Furthermore, Balangan District Government established The State High School of Paringin 2 and the, alumni of The private Middle School, were also given the opportunity to be able to continue at The High School Al Mazaya of Banjarmasin, which is also based on bilingual.

Fifthly, the Program constraints observed from the implementation of a bilingual schoolare based on the uneven ability of students to master English. However, the background of different dialect skills and adaptability in a bilingual environment is often the reason for the diverse abilities of students because Schools provide enrichment, via additional programs that aim at students who have not been able catch up to speak English fluently.

The importance of professional development for bilingual teachers is very good if the Office and Culture provides an opportunity, which is further facilitated to take part in an international scientific forum for teachers in bilingual schools, in an attempt to improve language skills and learning in multilingual schools on an ongoing basis.

Proof of ability to speak a language for all staff was very important, as Structured planning by the Principal, in terms of certification for Educators and Education Personnel is very good on the long-term bilingual program.

Furthermore, the teachers are very important part of the bilingual program as they are expected to always hone themselves with good language skills, especially in English skills (oral and written), hence it was good for them to take an English language proficiency test, including TOEFL, TOEIC etc and also regularly take part in a scientific forum of language teaching .

It is however expected that further researches should focus on just one aspect of management hence they can appreciate specifically the ideal bilingual school, especially in South Kalimantan.

\section{Acknowledgment}

The researchers express their gratitude to the supervisors who provided a very useful path, as well as the schools that has provided the opportunity to conduct this investigation. Furthermore, the editorial works of the j-k6em journal and all parties who also helped in the publication of this scientific work were also appreciated hence may the good deeds that have been given to us be answered by Allah Almighty, with abundant replies.

\section{Reference}

Alamsyah. (2019). School Based Management Implementation To Improve School Quality Of Multi Sites Study in SDN Alalak Selatan 2 and SDN Alalak Selatan 4 Banjarmasin City. IJSDR, 4(I), I38.

Chin, \& Wiggleworth. (2007). Bilingualism: an Advances Resources Book. Abidgon: Routledge.

Karsa, Y. A. (2018). Contribution of Learning Management and Emotional Intelligence to Performance and Work Effectiveness of Teachers at Public Elementary School in Barambai Sub-District. IOSR Journal of Research \& Method in Education, 8(6), 26.

Lee. (2008). Interdisciplinary Collaboration in English Language Teaching: Some Observation from Subject Teacher's Reflection. Reflection on English Language Teaching.

Mulyasa, E. (2009). Manajemen Berbasis Sekolah: Konsep, Strategi, dan Implementasi. Bandung: PT Remaja Rosdakarya.

Permadi, M. A. (2019). The Relationship Of Work Motivation And The Use Of Communication and Information Technology (TIK) With Quality Service At Islamic School (MAN) In Banjarmasin, Indonesia. European Journal of Alternative Education Studies, 4(I), 72.

Pranowo. (2005). Teori Belajar Bahasa: Untuk Pendidik Bahasa dan Mahasiswa Jurusan Bahasa. Yogyakarta: Pustaka Pelajar.

Rachmadinoor. (2018). Role of School Heads in Improving Quality of Education. IJSDR, 3(I2), 72 .

Salasiah. (2018). Instilling Character Values In Early Childhood In The Perspective Of Curriculum And Parenting (Multi-Site Study in Paud Islam Sabilal Muhtadin And PAUD Mawaddah, 
Banjarmasin, Indonesia). European Journal of Education Studies, 5(7), 46.

Suhaimi, \& Efendi, N. (2018). Hubungan Peran Kepala Sekolah Dan Sikap Terhadap Profesi Guru Dengan Prestasi Kerja Guru SMA Negeri di Kabupaten Hulu Sungai Selatan. Lentera Jurnal Ilmiah Kependidikan, I3(I), 73-83.

Suhaimi, \& Khalik, A. (2018). Kepemimpinan Transformasional Kepala Sekolah pada SMP Muhammadiyah 4 Banjarmasin. Jurnal Penelitian Tindakan dan Pendidikan, 4(I), 40.

Suhaimi, \& Rinawati, Y. (2018, December). The Management of Character Education Curriculum at Vocational High School 2 Kandangan. Paper presented at Ist
International Conference on Creativity, Innovation, Technology in Education Retrieved from https://download.atlantispress.com/article/55909600.pdf.

Suprihatin. (2004). Manajemen Sekolah. Semarang: UNNES PRESS.

Suriansyah, A. (2014). Hubungan Budaya Sekolah, Komunikasi, dan Komitmen Kerja. Cakrawala Pendidikan, 33(3), 365.

Suriansyah, A., \& Aslamiyah. (2015). Strategi Kepemimpinan Kepala Sekolah, Guru, Orang Tua dan Masyarakat Dalam Membentuk Karakter Siswa. Cakrawala Pendidikan, 34(02), 238. 